\title{
4
}

\section{Civil Society and Social Capital}

\begin{abstract}
This chapter explores how humans collaborate with others outside their families and households to expand capabilities for wellbeing, particularly by creating and participating in civil society institutions. The chapter also analyses social capital and how it can be increased through mechanisms that include: learning in schools; participation in networks; enforcement of norms; development of societal aspirations; and efforts for social inclusion. There are tensions between cultural capital (discussed in the previous chapter) and social capital (this chapter) since access to the services of social capital—especially to bridging social capital - is much easier for people who share the cultural capital of the community's dominant social group. Policy can enhance capabilities for wellbeing by ensuring persons are not disadvantaged as a result of ethnicity or other personal characteristic in their equitable access to services from all forms of capital.
\end{abstract}

Keywords Social capital • Wellbeing • Civil society • Structural racism • Interculturalism

We humans are social beings. Consistent with that observation, Chap. 3 has described how most of us cohabit with other people for long periods of our lives. This book now turns to how we humans collaborate outside our families and households to expand capabilities for wellbeing. This chapter focuses on 
collaboration in what is termed the third sector (Etzioni 1973; Corry 2010) or civil society (Seligman 1992; Dekker and van den Broek 1998; Fukuyama 2001; Office for Civil Society 2010).

Despite nuanced differences in definitions offered for this aspect of social life, there is general agreement that the institutional core of civil society is "constituted by voluntary associations outside the sphere of the state and the economy" (Flyvbjerg 1998, p. 210; see also Kumar 1993, and Seligman 2002). Persons support these associations by donating time and finance to pursue common interests and shared values. In the UK Community Life Survey of 2015-2016, for example, 47 per cent of respondents reported providing unpaid service to a volunteer organisation at least once a month (70 per cent reported doing so at least once a year), and 73 per cent reported making a financial donation to charity during an average four-week period (Cabinet Office 2016). The first section of this chapter discusses these civil society institutions and their contribution to wellbeing.

A closely related idea, which is adopted in many wellbeing frameworks, is social capital (see the survey in Scrivens and Smith 2013, part 3). This conveys the idea that social collaboration is easier when people are strongly connected to each other through established relationships in diverse social networks and by sharing accepted social norms (such as trust and civic co-operation; see Knack and Keefer 1997). This concept is explored in the second section, with a discussion of how social capital can be strengthened through learning in schools, participation in networks, enforcement of norms, development of societal aspirations and efforts for social inclusion.

The chapter's third section focuses on social capital and ethnicity, observing that there are tensions between the concept of cultural capital discussed in the previous chapter and the concept of social capital discussed in this chapter. These tensions exist because access to services from social capital-especially from what is termed bridging social capital—is much easier for people who share the cultural capital of a community's dominant cultural group. This creates and maintains privilege for the dominant group, to the disadvantage of outsiders' wellbeing, so that reflective action is required to redress the balance. The chapter finishes with a brief conclusion.

\section{The Institutions of Civil Society}

In an open society, people create diverse social institutions to pursue common goals and shared values. ${ }^{1}$ The National Council for Voluntary Organisations, for example, publishes data on UK institutions that inhabit the civil society space 
between state, businesses and individuals (NCVO 2017). Table 4.1 presents a count of the 390,000 formally incorporated organisations fitting that description. This sizeable number is not the full extent of voluntary collaboration by British citizens; the NCVO suggests 600,000 to 900,000 unincorporated associations could also be included in a broader definition of civil society (idem). The scale of activity that takes place in these incorporated and unincorporated institutions gives rise to our tenth proposition.

Proposition 10 Persons can access enhanced capabilities for wellbeing by participating in institutions of civil society to collaborate with others in the pursuit of common interests and shared values.

Civil society collaborations can be motivated by a desire to exclude outsiders (this is discussed below), but there are also strong elements of altruism and philanthropy. The largest category in Table 4.1 is comprised of general charities, which covers institutions that satisfy six criteria:

Table 4.1 Number of civil society incorporated organisations by organisation type, United Kingdom, 2013-2014

\begin{tabular}{ll}
\hline Organisation Type & Number of Organisations \\
\hline General charities (2014-2015 data) & 165,801 \\
Sports clubs & 135,900 \\
Companies limited by guarantee & 46,238 \\
Religious bodies & 38,383 \\
Community interest companies & 9177 \\
Co-operatives & 5568 \\
Trade associations and professional bodies & 3900 \\
Independent schools & 2598 \\
Housing associations & 1862 \\
Benevolent societies & 1681 \\
Credit unions & 521 \\
Political parties & 447 \\
Employee owned businesses & 250 \\
Football/rugby supporter trusts & 185 \\
Trade unions & 163 \\
Universities & 163 \\
Leisure trusts & 125 \\
Friendly societies and mutual insurers & 100 \\
Common investment funds & 55 \\
Building societies & 44 \\
LESS: Duplicates in the above list & $(23,510)$ \\
Total & 389,651 \\
\hline
\end{tabular}

Source: NCVO (2017, Civil Society Data) 
- Registration as a general charity (including a public benefit test)

- Formality (institutionalised to some extent)

- Independence (separate from the state)

- Non-profit distributing (profits not returned to owners or directors)

- Self-governance

- Voluntarism (some meaningful degree of voluntary participation)

Table 4.2 gives further details of this category, grouping the general charities in a list of primary activities adapted from Salamon and Anheier (1996). The largest group has social services as the primary purpose. Members in this group volunteer time and money to provide assistance to people in their communities who are experiencing difficulties. Thus, the common interests and values in these institutions centre on philanthropy and altruism, which can be recognised as important elements in civil society.

A good example is the network of Citizens Advice Bureaux operating in about 3000 locations throughout the United Kingdom. In 2015-2016, the Bureaux provided help to 3.1 million people directly, as well as many more who accessed Citizens Advice web pages. That assistance was offered by professional staff and

Table 4.2 Number of voluntary organisations registered as charities by area of activity, United Kingdom, 2014-2015

\begin{tabular}{ll}
\hline & Number of Organisations \\
\hline Social services & 30,265 \\
Culture and recreation & 23,586 \\
Religion & 14,357 \\
Grant-making foundations & 12,753 \\
Parent-teacher associations & 12,252 \\
Development & 10,286 \\
Education & 7914 \\
Village halls & 7662 \\
Playgroups and nurseries & 6960 \\
Health & 6710 \\
Scout groups and youth clubs & 6462 \\
International & 6055 \\
Environment & 5922 \\
Law and advocacy & 4270 \\
Housing & 3662 \\
Research & 3504 \\
Employment and training & 1985 \\
Umbrella bodies & 1156 \\
Not classified & 40 \\
Total & 165,801 \\
\hline
\end{tabular}

Source: NCVO (2017, Scope Data) 
more than 24,200 volunteers. The volunteered time was a substantial commitment, shown by calculating how much it would have cost for the same services to be provided by the professional staff (Citizens Advice 2014, fn. 2, p. 4). In 2015-2016, this was estimated to be $£ 114$ million in England and Wales, and $£ 10$ million in Scotland. ${ }^{2}$

Moving beyond this example, the Office of National Statistics uses survey data to estimate the value of volunteer time across all UK civil society institutions (ONS 2016; 2017). It focuses on people engaged in frequent formal volunteering; that is, residents who donate time at least once a month to a recognised institution. Figure 4.1 shows estimates for the decade 2005-2014. The impact of inflation has been removed from the series. Despite population growth over the same period, there is a downward trend. This is because the average time volunteered per person declined significantly over the decade, by 19.3 per cent (ONS 2016, pp. 40-41).

The estimates in Fig. 4.1 indicate the income volunteers might have earned if they had offered the same services in paid employment. Recall that Chap. 2 used this conceptualisation to estimate the opportunity cost of time spent by people in any valued activity (see the discussion around Fig. 2.1). The same understanding can be applied here, with some caveats. Volunteers participate in

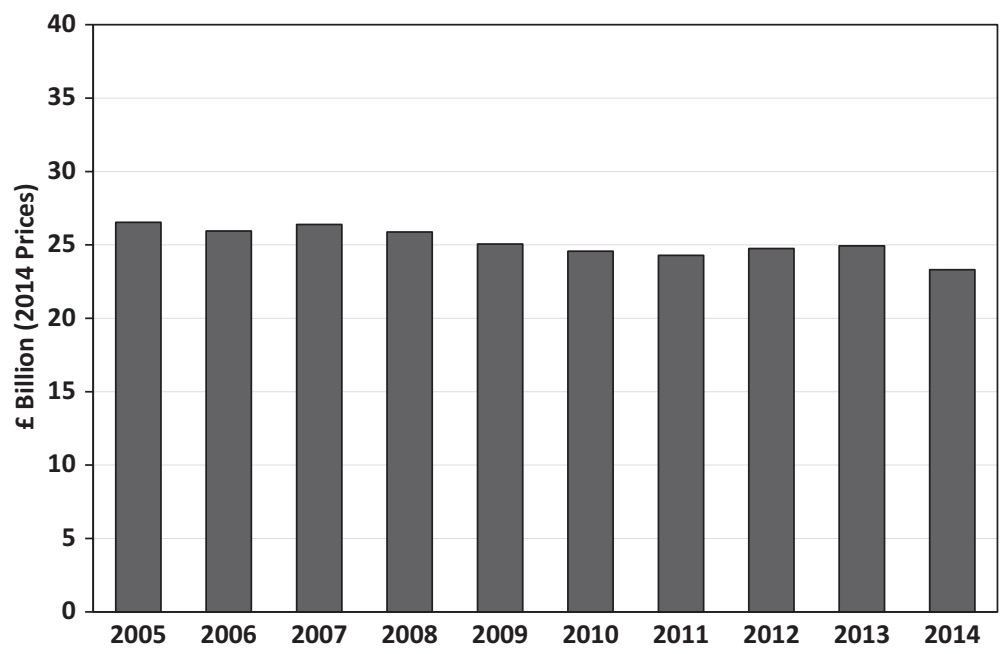

Fig. 4.1 Gross value added of frequent formal volunteering measured in 2014 prices, United Kingdom, 2005-2014. (Note: The impact of inflation has been removed using the GDP Deflator at Market Prices. Source: ONS (2016, Fig. 8.2, p. 41) and HM Treasury (2017)) 
training and gain experience; hence, some of the time represents investment in developing human capital. Similarly, volunteering introduces persons to new social networks, opening up access to the community's social capital (see the following section). Even allowing for these caveats, however, the high opportunity cost of volunteered time recorded in Fig. 4.1 suggests that, at least for some persons, living a valued kind of life includes helping other people (see Fujiwara et al. 2013; Jenkinson et al. 2013).

\section{Social Capital}

In 2008, the UK Government's Foresight Project on mental capital and wellbeing commissioned the New Economics Foundation to develop a set of evidencebased actions that people can take to improve personal wellbeing. The resulting review of the science literature identified five actions that can be good for mental wellbeing if built into daily life. They are worth citing in full (Aked et al. 2008, p. iii; Aked and Thompson 2011, p. 8):

\section{Connect...}

With the people around you. With family, friends, colleagues and neighbours. At home, work, school or in your local community. Think of these as the cornerstones of your life and invest time in developing them. Building these connections will support and enrich you every day.

\section{Be active...}

Go for a walk or run. Step outside. Cycle. Play a game. Garden. Dance. Exercising makes you feel good. Most importantly, discover a physical activity you enjoy and that suits your level of mobility and fitness.

\section{Take notice...}

Be curious. Catch sight of the beautiful. Remark on the unusual. Notice the changing seasons. Savour the moment, whether you are walking to work, eating lunch or talking to friends. Be aware of the world around you and what you are feeling. Reflecting on your experiences will help you appreciate what matters to you.

\section{Keep learning...}

Try something new. Rediscover an old interest. Sign up for that course. Take on a different responsibility at work. Fix a bike. Learn to play an instrument or how to cook your favourite food. Set a challenge you will enjoy achieving. Learning new things will make you more confident as well as being fun. 


\section{Give...}

Do something nice for a friend, or a stranger. Thank someone. Smile. Volunteer your time. Join a community group. Look out, as well as in. Seeing yourself, and your happiness, linked to the wider community can be incredibly rewarding and creates connections with the people around you.

These five ways to wellbeing involve going outside a person's immediate family and household. Moving beyond the relative safety of kith and kin, however, is also associated with risks to wellbeing, including potential harm arising from public shame and humiliation (Sen 1983, p. 159; Zavaleta Reyles 2007). This was recognised in a famous passage of The Wealth of Nations (Smith 1776, Vol. 2, pp. 399-400):

But in the present times, through a greater part of Europe, a creditable day-labourer would be ashamed to appear in public without a linen shirt, the want of which would be supposed to denote that disgraceful degree of poverty which, it is presumed, nobody can well fall into without extreme bad conduct.

More recently, Wilkinson and Pickett (2009) have drawn on research by Scheff (1988) and Dickerson and Kemeny (2004) to argue that residents who live in countries with more inequality are vulnerable to greater anxiety about potential shame for low or falling social status. Anxiety leads to poorer national outcomes across multiple indicators of wellbeing. On this theme, Walker and Chase (2013) and Kent (2016) have documented how poverty debates in the United Kingdom have become dominated by private and public sector efforts to shame citizens judged as undeserving of welfare assistance.

Further social barriers exist when it is not always safe to trust others in dayto-day social relations (Fukuyama 1995), particularly if social and political institutions are not trustworthy (O'Neill 2002). In some countries, this can be because the State actively suppresses civil society institutions (Bernhard 1993; Chamberlain 1993). In some societies, it can be socially accepted for a person to promote interests of family and friends over the civil rights of a stranger, even when acting as a public official (Fukuyama 2001, p. 9). Indeed, a country's legal system can include laws and regulations designed to prevent members of specified social groups from participating in high status occupations or engaging in important public activities (Dasgupta 2005; Clark and Worger 2016).

Observations such as these lead to the idea that social collaboration is easier in some communities than in others. Expressing this idea using the capital stock metaphor, communities in which people find it easier to co-operate are said to 
have higher levels of social capital than communities where collaboration is more difficult (Knack and Keefer 1997; Woolcock 1998). This metaphor is not easily explained (Scrivens and Smith 2013, p. 11), to the extent that Manski (2000, p. 123) suggests "economists should use 'social capital' only as a lesson in the ambiguity of words". Nevertheless, the following definitions capture different aspects of the term:

... "social capital" refers to features of social organization such as networks, norms, and social trust that facilitate coordination and cooperation for mutual benefit. (Putnam 1995a, p. 67)

The social capital of a society includes the institutions, the relationships, the attitudes and values that govern interactions among people and contribute to economic and social development. (World Bank 1998, p. 1)

Social capital is the shared knowledge, understandings, norms, rules, and expectations about patterns of interactions that groups of individuals bring to a recurrent activity. (Ostrom 2000, p. 176)

... the definition of social capital is: networks together with shared norms, values and understandings that facilitate co-operation within or among groups. (OECD 2001, p. 41)

Social capital generally refers to trust, concern for one's associates, a willingness to live by the norms of one's community and to punish those who do not. (Bowles and Gintis 2002, p. F419)

A widely adopted classification recognises three forms of social capital (Szreter and Woolcock 2004; Keeley 2007, p. 103; Poortinga 2012). Bonding social capital draws together groups of relatively homogenous people bound by considerations such as family, ethnicity, gender or social class. Bridging social capital supports collaboration among diverse social groups in a region or country. Linking social capital makes it easier for people to connect with the country's major institutions exercising power, including local, regional and national government.

Bonding capital may be strong within each community of a country at the same time that bridging capital between different communities is weak. Sectarian conflict in Northern Ireland has been cited as an example (Leonard 2004; Campbell et al. 2010). Similarly, access to linking social capital may be far easier for members of some communities than for others, to the extent that some 
groups of citizens can be systematically disadvantaged in interactions with the country's education, health, police and justice systems (Eddo-Lodge 2017, Chap. 2; see also the following section).

The capital metaphor recognises that social capital can deteriorate with neglect, just as physical capital depreciates without maintenance, but can also be increased with suitable investment. ${ }^{3}$ The first of these characteristics motivated Robert Putnam (1995a, 2000) to lament what he saw as the decline of social capital in the United States over the previous three decades, reflected in his symbol of an individual "bowling alone" rather than participating with others in organised competitions.

Putnam's diagnosis has been criticised for overstating the extent of the problem and for failing to distinguish causes and effects of changes in the stock of social capital (Portes 1998, pp. 18-21). Hall (1999), for example, found no evidence of an equivalent erosion of social capital in the United Kingdom (although this may be changing this century; see Richards and Heath 2015, and Fig. 4.1 above). Nevertheless, there has been progress in understanding how investment in social capital can take place, summarised in the following proposition and explained in the remainder of this section.

Proposition 11 Investment in social capital can occur through mechanisms that include: learning in schools; participation in networks; enforcement of norms; development of societal aspirations and efforts for social inclusion.

Learning in Schools Fukuyama (1999, p. 257) observes that "one of the most important sources of social capital in contemporary societies is the educational system". At school, young people learn how to collaborate with others outside their immediate family circle, including through participation in well-structured programmes of physical education (Bailey et al. 2013). Citizenship programmes may be included in a national curriculum (Department for Education 2013).

Putnam (1995b, p. 667) observes the powerful effects of schooling on later social and political participation, concluding: "highly educated people are much more likely to be joiners and trusters, partly because they are better off economically, but mostly because of the skills, resources, and inclinations that were imparted to them at home and in school”. Hall (1999, pp. 435-437) similarly observes that radical transformation in the British education system between the 1950s and 1990s reduced segregation by class and gender, and increased attainment, which positively affected the country's social capital. 
Participation in Networks A key idea in Coleman's (1986) original essay is that social capital grows when persons participate in social networks, but this does not occur to the extent needed to maximise aggregate wellbeing because a large share of the benefits accrues to people other than the decision-maker. This is because the personal benefits of greater social capital are not restricted to a person's own individual contribution.

Thus, social capital has a "public good" element (see Chap. 6 for further discussion on economic public goods), which tends to limit the scope for collaboration. To be successful, voluntary organisations must find ways to foster "a cooperative spirit, norms of reciprocity, and collective thinking beyond the boundaries of the group itself" (Stolle and Rochon 1998, p. 49). The public good element of participation in social networks can justify supportive public policies (Hall 1999, pp. 440-443). ${ }^{4}$

Enforcement of Norms The social capital definition of Bowles and Gintis (2002) cited above includes willingness to punish violations of community norms (see also Paldam and Svendsen 2000, section 4, and Dasgupta 2005, pp. S6-S7). To illustrate, suppose a person travelling on a bus is subjected to sustained verbal abuse; can the person rely on other passengers to intervene so that community norms of courtesy and respect are enforced? If the answer is no, then social capital is weak.

Similar to participation in networks, enforcement of norms has a public good element (benefits are enjoyed by a wider group than the enforcer), which is one of several reasons for funding judicial systems from the public purse. The development of human rights legislation has been important for building social capital, by providing a mechanism to enforce fundamental rights such as freedom from unfair discrimination and protection of private property.

Development of Societal Aspirations There is a substantial literature on tensions between individual freedoms and societal aspirations. Margaret Thatcher famously claimed while UK Prime Minister that "there is no such thing as society"; instead "there is living tapestry of men and women and people" (Thatcher 1987, pp. 30-31). That attitude reflects what Francis Fukuyama (1999, pp. 5-6) has labelled a Great Disruption in social values from the mid-1960s to the early 1990 s, which he suggests resulted in a culture of "intensive individualism" that "weakened the bonds holding families, neighborhoods, and nations together". 
In contrast, social capital can be strengthened when countries develop societal aspirations or common goals. This involves, but is not limited to, the political process. Societal aspirations must be supported by community rules that Fukuyama observes will always entail some limits to individual freedoms to facilitate new forms of collaboration and connectedness (idem, p. 15).

Efforts for Social Inclusion In his UK study, Peter Hall reported that access to social capital is unevenly distributed among the British population, to the extent that "the more accurate image is of a nation divided between a well-connected and highly-active group of citizens with generally prosperous lives and another set of citizens whose associational life and involvement in politics are very limited" (Hall 1999, p. 455). A later study similarly concluded that social capital in Britain operates to entrench privilege within and across generations, so that "encouraging greater formal civic engagement without tackling the root causes of socio-economic disadvantage may well aggravate rather than ameliorate social division" (Li et al. 2008, p. 407).

These observations suggest that efforts to promote social inclusion, initiated in both the private and public sectors, are required to strengthen access by all citizens to the services provided by the country's social capital. This is discussed in the following section.

\section{Social Capital and Ethnicity}

The social capital definitions listed in the previous section all refer to shared values or norms. Cultural values and accepted norms were discussed in Chap. 3, which observed that they are learned by young persons within families and households. This was labelled as cultural capital, which differs from social capital in two important respects.

First, cultural capital in its primary sense is embodied in persons, whereas social capital "exists in the relations among persons" (Coleman 1986, pp. S100S101). 5 Second, while both types of capital are continuously transformed in a healthy society, cultural capital is conceptualised as connecting a person with previous and future generations (through the transmission of cultural heritage), whereas social capital connects a person with others in the current generation of living people. 
There are inevitable tensions between cultural and social capital, since history shows repeatedly that access to services from a community's social capital (as well as access to other private and public resources) is much easier for people who share the cultural capital of the community's dominant social group. Indeed, this was a central message of Pierre Bourdieu's $(1973,1983)$ research, which developed the concept of cultural capital to explain why children from wealthy households achieve better results at school than children from lower socioeconomic groups.

Recall the example in the previous section of a bus passenger subjected to sustained verbal abuse. The answer to whether the passenger can rely on others to intervene may depend on the abused person's ethnicity (see, for example, Qureshi 2017). If so, this is a community where access to services from social capital—especially from bridging social capital—is limited for people outside the dominant cultural group.

Further, shared norms held by the dominant group may include general acceptance, perhaps unvoiced, that it is legitimate for its members to treat people from other ethnic groups in a hostile manner that would be sanctioned if applied to anyone from the dominant group. This can include using humiliating language, acting with dishonest intent, providing discriminatory standards of service, denying entry to certain networks or clubs, or tolerating an ever-present threat of physical assault that generally goes unpunished (Coates 2015).

These possibilities represent "the dark side of social capital" (Portes 1998, pp. 15-18; Gargiulo and Benassi 1999; Putnam 2000, Chap. 22; Dasgupta 2005, p. S17; van Deth and Zmerli 2010; Scrivens and Smith 2013, p. 23). An often-cited study by Waldinger (1995) gave an example of how insiders of white ethnicity in the New York construction sector effectively mobilised social capital to sustain economic advantage at the expense of African-American, Caribbean and Korean outsiders. ${ }^{6}$

Reni Eddo-Lodge (2017, Chap. 3) has called this phenomenon "white privilege", which a black person can only watch "as an outsider to the insularity of whiteness" (idem, p. 86). She goes on to say (idem, p. 87):

When I talk about white privilege, I don't mean that white people have it easy, that they've never struggled, or that they've never lived in poverty. But white privilege is the fact that if you're white, your race will almost certainly positively impact your life's trajectory in some way. And you probably won't even notice it.

The tendency for members of the dominant culture to be advantaged over outsiders is not restricted to individual behaviour. It can occur in the country's 
state and civil society organisations, where it is labelled institutional or cultural discrimination (Dovidio et al. 2010, pp. 10-11), or structural racism (EddoLodge 2017, p. 64). The Stephen Lawrence inquiry, for example, acknowledged institutional racism in the Metropolitan Police Service, which it defined as (Macpherson 1999, section 6.34):

The collective failure of an organisation to provide an appropriate and professional service to people because of their colour, culture, or ethnic origin. It can be seen or detected in processes, attitudes and behaviour which amount to discrimination through unwitting prejudice, ignorance, thoughtlessness and racist stereotyping which disadvantage minority ethnic people.

Eddo-Lodge observes that the dominant group tend not to notice their advantage, while Macpherson speaks of prejudice that is unwitting. This is often how social capital operates. It is a resource that insiders find they can draw upon easily, or without conscious thought, while outsiders find they must collectively organise sustained social action to obtain some degree of equitable access to its services. Using terms introduced in Chap. 2, the result of this social structure is that persons with similar personal abilities find they have unequal social capabilities depending on their ethnicity or some other personal characteristic.

Such an outcome is a fundamental challenge to policy. In the language of this book, equitable access to services from all forms of capital is necessary for citizens to have reasoned capabilities for leading valued lives. When large numbers of citizens, because of ethnicity or some other characteristic, face systematic limitations on their access to services from the country's shared social capital, the capabilities of those citizens for leading valued lives are reduced and wellbeing is stunted. This leads to the following proposition.

Proposition 12 Policy can enhance capabilities for wellbeing by ensuring persons are not disadvantaged in their equitable access to services from the country's capital stocks because of ethnicity or other personal characteristics.

Note that Proposition 12 goes well beyond the Pareto efficiency criterion for policy advice discussed in the opening chapter. This criterion supports economic policies if at least one person's wellbeing is improved and no one is made worse off. In contrast, Proposition 12 sanctions proposals in which members of the dominant cultural group sacrifice historical privilege in order to improve equitable access of other people to the country's social capital. It is possible that 
increasing the capabilities of people from minority groups would raise aggregate economic productivity to everyone's potential benefit (see Arrow et al. 2000), but this is not presumed in Proposition 12.

One way to address Proposition 12 is through efforts by individuals, private businesses, public officials and civil society institutions to foster interaction and dialogue among different cultural traditions. A term that has emerged for these efforts is interculturalism (Cantle 2012; Meer and Modood 2012; Taylor 2012; Zapata-Barrero 2015; Meer et al. 2016). The Council of Europe, for example, funds an Intercultural Cities Programme (Wood and Landry 2008; ICC 2016) that builds capacity, offers strategies and initiates projects to strengthen inclusive approaches that support diversity in cities.

\section{Conclusion}

Collaborations with people outside a person's immediate family and household can greatly expand personal and social capabilities for wellbeing. In a free society, there is scope for a large number of diverse organisations to bring persons together to collaborate in the pursuit of common interests and shared values, supported by financial donations and volunteered time. These institutions make up the core of civil society.

Social capital is a metaphor reflecting the idea that interconnections among people contribute to wellbeing in a number of important ways. Social capital can be strengthened by conscious efforts in the private and public spheres, including through: learning in schools; participation in networks; enforcement of norms; development of societal aspirations; and efforts for social inclusion.

This chapter discussed social capital and ethnicity. This drew on Eddo-Lodge's (2017) recent book, supporting its insistence that members of the dominant social group take active measures to sacrifice historical privilege in order to improve equitable access of other people to the country's social capital. This finished by highlighting efforts by individuals, private businesses, public officials and civil society institutions to foster interculturalism.

Having considered choices made at the levels of individual persons, of households and families, and of communities, the stage is now set for the middle chapter of this book. It examines how participation in the market economy can contribute to expanded wellbeing, especially as a result of firms maintaining specialised capabilities for supplying goods and services needed by persons to live the kinds of lives they value. 


\section{Notes}

1. The key philosophical text on open societies is Karl Popper's The Open Society and Its Enemies, first published in two volumes in 1945, republished as one volume by Princeton University Press in Popper (2013).

2. These and other data in this paragraph are drawn from Citizens Advice (2016), Citizens Advice Northern Island (2015) and Citizens Advice Scotland (2016).

3. Bowles and Gintis (2002, pp. F420-F421) object to this metaphor on the grounds that "capital refers to something that can be owned". They therefore propose an alternative conceptualisation of "community governance".

4. The value of participation in social networks leads Layard (2006, p. C32) to warn economists not to advocate greater worker mobility (to generate higher incomes) without considering the associated effects on the quality of relationships in the community and in families.

5. Glaeser et al. (2002, p. F438) object to the view of social capital as a communitylevel attribute "because economists find it difficult to think of communities as decision-makers" (ibid). They therefore define individual social capital to be embodied in a person, and aggregate social capital is calculated as a function of these individual social characteristics. We do think that approach is fruitful; the key issue in our view is access to services provided by social capital.

6. Insider-outside behaviour is well understood by economists, especially in a labour market context; see, for example, Solow (1985) and Lindbeck and Snower (1988, 2001).

\section{References}

Aked, Jody, and Sam Thompson. 2011. Five Ways to Wellbeing: New Applications, New Ways of Thinking. London: New Economics Foundation.

Aked, Jody, Nic Marks, Corrina Cordon, and Sam Thompson. 2008. Five Ways to Wellbeing. London: New Economics Foundation.

Arrow, Kenneth, Samuel Bowles, and Steven Durlauf, eds. 2000. Meritocracy and Economic Inequality. Princeton, NJ: Princeton University Press.

Bailey, Richard, Charles Hillman, Shawn Arent, and Albert Petitpas. 2013. Physical Activity: An Underestimated Investment in Human Capital. Journal of Physical Activity \& Health 10 (3): 289-308.

Bernhard, Michael. 1993. Civil Society and Democratic Transition in East Central Europe. Political Science Quarterly 108 (2): 307-326.

Bourdieu, Pierre. 1973. Cultural Reproduction and Social Reproduction. In Knowledge, Education and Cultural Change: Papers in the Sociology of Education, ed. Richard K. Brown, 71-112. London: Tavistock. 
1983. Ökonomisches Kapital, Kulturelles Kapital, Soziales Kapital. In Soziale Ungleichheiten (Soziale Welt, Sonderheft 2), ed. Reinhard Kreckel, 183-198. Goettingen: Otto Schartz. Translated by Richard Nice and republished as The Forms of Capital in Handbook of Theory and Research for the Sociology of Education, ed. John C. Richardson, 241-258. Westport, CT: Greenwood Publishing Group, 1986.

Bowles, Samuel, and Herbert Gintis. 2002. Social Capital and Community Governance. Economic Journal 112 (483, Features): F419-F436.

Cabinet Office. 2016. Community Life Survey 2015-16 Statistical Bulletin. London: Cabinet Office Official Statistics.

Campbell, Andrea, Joanne Hughes, Miles Hewstone, and Cairns Ed. 2010. Social Capital as a Mechanism for Building a Sustainable Society in Northern Ireland. Community Development Journal 45 (1): 22-38.

Cantle, Ted. 2012. Interculturalism: The New Era of Cohesion and Diversity. Houndmills: Palgrave Macmillan.

Chamberlain, Heath B. 1993. On the Search for Civil Society in China. Modern China 19 (2): 199-215.

Citizens Advice. 2014. CAB Volunteering - How Everyone Benefits. London: Citizens Advice.

- 2016. Helping People Find a Way Forward: A Snapshot of Our Impact in 2015/16. London: Citizens Advice.

Citizens Advice Northern Ireland. 2015. One Service, Looking Forward: Annual Report 2014-2015. Belfast: Citizens Advice Northern Ireland.

Citizens Advice Scotland. 2016. Face Value: Impact Report 2015/16. Edinburgh: Citizens Advice Scotland.

Clark, Nancy L., and William H. Worger. 2016. South Africa: The Rise and Fall of Apartheid. 3rd ed. London/New York: Routledge.

Coates, Ta-Neshi. 2015. Between the World and Me. Melbourne: Text Publishing.

Coleman, James S. 1986. Social Capital in the Creation of Human Capital. American Journal of Sociology 94 (Supplement): S95-S120.

Corry. Olaf. 2010. Defining and Theorizing the Third Sector. In Third Sector Research, ed. Rupert Taylor, 11-20. New York: Springer.

Dasgupta, Partha. 2005. Economics of Social Capital. Economic Record 81 (S1): S2-S21.

Dekker, Paul, and Andries van den Broek. 1998. Civil Society in Comparative Perspective: Involvement in Voluntary Associations in North America and Western Europe. Voluntas: International Journal of Voluntary and Nonprofit Organisations 9 (1): $11-38$.

Department for Education. 2013. Citizenship Programmes of Study: Key Stages 3 and 4. GOV.UK website. https://www.gov.uk/government/collections/national-curriculum. Accessed 3 Oct 2017.

Dickerson, Sally, and Margaret E. Kemeny. 2004. Acute Stressors and Cortisol Responses: A Theoretical Integration and Synthesis of Laboratory Research. Psychological Bulletin 130 (3): 355-391. 
Dovidio, John F., Miles Hewstone, Peter Glick, and Victoria M. Esses. 2010. Prejudice, Stereotyping and Discrimination: Theoretical and Empirical Overview. In The SAGE Handbook of Prejudice, Stereotyping and Discrimination, ed. John F. Dovidio, Miles Hewstone, Peter Glick, and Victoria M. Esses, 3-28. London: SAGE Publications.

Eddo-Lodge, Reni. 2017. Why I'm No Longer Talking to White People About Race. London: Bloomsbury Circus.

Etzioni, Amitai. 1973. The Third Sector and Domestic Missions. Public Administration Review 33 (4): 314-323.

Flyvbjerg, Bent. 1998. Habermas and Foucault: Thinkers for Civil Society? British Journal of Sociology 49 (2): 210-233.

Fujiwara, Daniel, Paul Oroyemi, and Ewen McKinnon. 2013. Wellbeing and Civil Society: Estimating the Value of Volunteering using Subjective Wellbeing Data. Working Paper No. 112. Sheffield: Department for Work and Pensions.

Fukuyama, Francis. 1995. Trust: The Social Virtues and the Creation of Prosperity. New York: Free Press.

- 1999. The Great Disruption: Human Nature and the Reconstitution of Social Order. New York: Free Press.

- 2001. Social Capital, Civil Society and Development. Third World Quarterly 22 (1): 7-20.

Gargiulo, Martin, and Mario Benassi. 1999. The Dark Side of Social Capital. In Corporate Social Capital and Liability, ed. Roger T.A.J. Leenders and Shaul M. Gabba, 298-322. Boston, MA: Springer.

Glaeser, Edward L., David Laibson, and Bruce Sacerdote. 2002. An Economic Approach to Social Capital. Economic Journal 112 (483, Features): F437-F458.

Hall, Peter A. 1999. Social Capital in Britain. British Journal of Political Science 29 (3): 417-461.

HM Treasury. 2017. GDP Deflators at Market Prices, and Money GDP: March 2017 (Spring Budget 2017). GOV.UK website. https://www.gov.uk/government/statistics/ gdp-deflators-at-market-prices-and-money-gdp-march-2017-spring-budget-2017. Accessed 23 Nov 2017.

ICC. 2016. Intercultural Cities Annual Report 2016: Sharing Our Cities Sharing the Future. Council of Europe Intercultural Cities Programme. https://rm.coe. int/16806c9674. Accessed 6 October 2017.

Jenkinson, Caroline E., Andy P. Dickens, Kerry Jones, Thompson-Coon Jo, Rod S. Taylor, Morwenna Rogers, Clare L. Bambra, Iain Lang, and Suzanne H. Richards. 2013. Is volunteering a public health intervention? A systematic review and metaanalysis of the health and survival of volunteers. BMC Public Health 13: 773. https:// doi.org/10.1186/1471-2458-13-773.

Keeley, Brian. 2007. Human Capital: How What You Know Shapes Your Life. OECD Insights. Paris: OECD Publishing. 
Kent, Gabi. 2016. Shattering the Silence: The Power of Purposeful Storytelling in Challenging Social Security Policy Discourses of 'Blame and Shame' in Northern Ireland. Critical Social Policy 36 (1): 124-141.

Knack, Stephen, and Philip Keefer. 1997. Does Social Capital Have an Economic Payoff? A Cross-Country Investigation. Quarterly Journal of Economics 112 (4): 1251-1288. Kumar, Krishan. 1993. Civil Society: An Inquiry into the Usefulness of an Historical Term. British Journal of Sociology 44 (3): 375-395.

Layard, Richard. 2006. Happiness and Public Policy: A Challenge to the Profession. Economic Journal 116 (510): C24-C33.

Leonard, Madeleine. 2004. Bonding and Bridging Social Capital: Reflections from Belfast. Sociology 38 (5): 927-944.

Li, Yaojun, Mike Savage, and Alan Warde. 2008. Social Mobility and Social Capital in Contemporary Britain. British Journal of Sociology 59 (3): 391-411.

Lindbeck, Assar, and Dennis J. Snower. 1988. Cooperation, Harassment, and Involuntary Unemployment: An Insider-Outsider Approach. American Economic Review 78 (1): 167-188.

- 2001. Insiders versus Outsiders. Journal of Economic Perspectives 15 (1): $165-188$.

Macpherson, Sir William. 1999. The Stephen Lawrence Inquiry, Cm 4262-I. https:// www.gov.uk/government/publications/the-stephen-lawrence-inquiry. Accessed 9 July 2017.

Manski, Charles F. 2000. Economic Analysis of Social Interactions. Journal of Economic Perspectives 14 (3): 115-136.

Meer, Nasar, and Tariq Modood. 2012. How Does Interculturalism Contrast with Multiculturalism? Journal of Intercultural Studies 33 (2): 175-196.

Meer, Nasar, Tariq Modood, and Richard Zapata-Barrero, eds. 2016. Multiculturalism and Interculturalism: Debating the Dividing Lines. Edinburgh: Edinburgh University Press.

NCVO. 2017. UK Civil Society Almanac 2017. London: National Council for Voluntary Organisations. https://data.ncvo.org.uk/. Database and text accessed 24 May 2017.

O'Neill, Onora. 2002. A Question of Trust: The BBC Reith Lectures 2002. Cambridge: Cambridge University Press.

OECD. 2001. The Well-being of Nations: The Role of Human and Social Capital. Paris: OECD Publishing https://doi.org/10.1787/9789264189515-en.

Office for Civil Society. 2010. Building a Stronger Civil Society: A Strategy for Voluntary and Community Groups, Charities and Social Enterprises. London: HM Government.

ONS. 2016. Household Satellite Accounts: 2005 to 2014. Compendium released 7 April. London: Office for National Statistics.

- 2017. Changes in the Value and Division of Unpaid Volunteering in the UK: 2000 to 2015. Article released 16 March. London: Office for National Statistics.

Ostrom, Elinor. 2000. Social Capital: A Fad or a Fundamental Concept? In Social Capital: A Multifaceted Approach, ed. Partha Dasgupta and Ismail Serageldin, 172-214. World Bank: Washington, DC. 
Paldam, Martin, and Gert Tinggaard Svendsen. 2000. An Essay on Social Capital: Looking for the Fire behind the Smoke. European Journal of Political Economy 16 (2): 339-366.

Poortinga, Wouter. 2012. Community Resilience and Health: The Role of Bonding, Bridging, and Linking Aspects of Social Capital. Health \& Place 18 (2): 286-295.

Popper, Karl. 2013. The Open Society and Its Enemies. Princeton, NJ: Princeton University Press.

Portes, Alejandro. 1998. Social Capital: Its Origins and Applications in Modern Sociology. American Review of Sociology 24: 1-24.

Putnam, Robert D. 1995a. Bowling Alone: America's Declining Social Capital. Journal of Democracy 6 (1): 65-78.

. 1995b. Tuning In, Tuning Out: The Strange Disappearance of Social Capital in America. PS: Political Science and Politics 28 (4): 664-683.

- 2000. Bowling Alone: The Collapse and Revival of American Community. New York: Simon \& Schuster.

Qureshi, Sadiah. 2017. Black and British: A Forgotten History by David Olusoga. London Review of Books 39 (14): 39-40.

Richards, Lindsay and Anthony Heath. 2015. The Uneven Distribution and Decline of Social Capital in Britain. CSI Briefing Note 15, Centre for Social Investigation, Nuffield College, Oxford. http://csi.nuff.ox.ac.uk/?page_id=89. Accessed 3 Oct 2017.

Salamon, Lester M. and Helmut K. Anheier. 1996. The International Classification of Nonprofit Organizations: ICNPO-Revision 1, 1996. Working Papers of the Johns Hopkins Comparative Nonprofit Sector Project, no. 19. Baltimore: The Johns Hopkins Institute for Policy Studies.

Scheff, Thomas J. 1988. Shame and Conformity: The Deference-Emotion System. American Sociological Review 53 (3): 395-406.

Scrivens, Katherine, and Conal Smith. 2013. Four Interpretations of Social Capital: An Agenda for Measurement. OECD Statistics Working Papers 2013/06. Paris: OECD Publishing at doi: https://doi.org/10.1787/5jzbcx010wmt-en.

Seligman, Adam B. 1992. The Idea of Civil Society. New York: The Free Press. - 2002. Civil Society as Idea and Ideal. In Alternative Conceptions of Civil Society, ed. Simone Chambers and Will Kymlicka, 13-33. Princeton, NJ: Princeton University Press.

Sen, Amartya. 1983. Development: Which Way Now? Presidential Address of the Development Studies Association. Economic Journal 93 (December): 745-762.

Smith, Adam (1776) An Enquiry into the Nature and Causes of the Wealth of Nations, 2 vols., University Paperbacks edition, ed. Edwin Cannan. London: Methuen.

Solow, Robert M. 1985. Insiders and Outsiders in Wage Determination. Scandinavian Journal of Economics 87 (2): 411-428.

Stolle, Dietlind, and Thomas R. Rochon. 1998. Are All Associations Alike? Member Diversity, Associational Type, and the Creation of Social Capital. American Behavioral Scientist 42 (1): 47-65. 
Szreter, Simon, and Michael Woolcock. 2004. Health by Association? Social Capital, Social Theory, and the Political Economy of Public Health. International Journal of Epidemiology 33 (4): 650-667.

Taylor, Charles. 2012. Interculturalism or Multiculturalism. Philosophy and Social Criticism 38 (4-5): 413-423.

Thatcher, Margaret. 1987. Interview for Woman's Own. Transcript of Interview with Journalist Douglas Keay, 23 September. https://www.margaretthatcher.org/document/106689. Accessed 3 Oct 2017.

van Deth, Jan W., and Sonja Zmerli. 2010. Introduction: Civicness, Equality, and Democracy-A "Dark Side" of Social Capital? American Behavioral Scientist 53 (5): 631-639.

Waldinger, Roger. 1995. The "Other Side" of Embeddedness: A Case-Study of the Interplay of Economy and Ethnicity. Ethnic and Racial Studies 18 (3): 555-580.

Walker, Robert, and Elaine Chase. 2013. Separating the Sheep from the Goats: Tackling Poverty in Britain for over Four Centuries. In The Shame of It: Global Perspectives on Anti-poverty Policies, ed. Erika K. Gubrium, Sony Pellissery, and Ivar Lødemel, 133-156. Bristol: Policy Press.

Wilkinson, Richard G., and Kate Pickett. 2009. The Spirit Level: Why More Equal Societies Almost Always Do Better. London: Allen Lane.

Wood, Phil, and Charles Landry. 2008. The Intercultural City: Planning for Diversity Advantage. London: Earthscan.

Woolcock, Michael. 1998. Social Capital and Economic Development: Toward a Theoretical Synthesis and Policy Framework. Theory and Society 27 (2): 151-208.

World Bank. 1998. The Initiative on Defining, Monitoring and Measuring Social Capital: Overview and Program Description. Social Capital Working Paper Series. Washington, DC: World Bank, Social Development Department.

Zapata-Barrero, Ricard. 2015. Interculturalism in Cities: Concept, Policy, and Implementation. Cheltenham: Edward Elgar.

Zavaleta Reyles, Diego. 2007. The Ability to go about Without Shame: A Proposal for Internationally Comparable Indicators of Shame and Humiliation. Oxford Development Studies 35 (4): 405-430. 
Open Access This chapter is licensed under the terms of the Creative Commons Attribution 4.0 International License (http://creativecommons.org/licenses/by/4.0/), which permits use, sharing, adaptation, distribution and reproduction in any medium or format, as long as you give appropriate credit to the original author(s) and the source, provide a link to the Creative Commons license and indicate if changes were made.

The images or other third party material in this chapter are included in the chapter's Creative Commons license, unless indicated otherwise in a credit line to the material. If material is not included in the chapter's Creative Commons license and your intended use is not permitted by statutory regulation or exceeds the permitted use, you will need to obtain permission directly from the copyright holder.

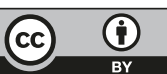

